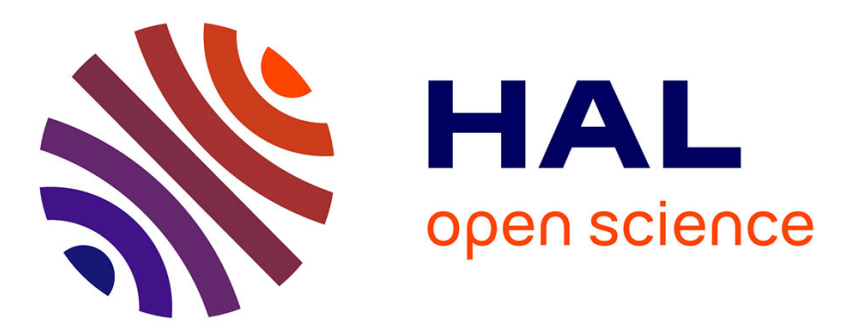

\title{
The results of 10 years of daily observations of the flux of suspended matter in one of the main water courses in the European Alps: the Isère at Grenoble (France)
}

Dominique Dumas

\section{- To cite this version:}

Dominique Dumas. The results of 10 years of daily observations of the flux of suspended matter in one of the main water courses in the European Alps: the Isère at Grenoble (France). Comptes Rendus Géoscience, 2007, 339 (13), pp.810-819. halshs-00281917

\section{HAL Id: halshs-00281917 \\ https://shs.hal.science/halshs-00281917}

Submitted on 14 Nov 2009

HAL is a multi-disciplinary open access archive for the deposit and dissemination of scientific research documents, whether they are published or not. The documents may come from teaching and research institutions in France or abroad, or from public or private research centers.
L'archive ouverte pluridisciplinaire HAL, est destinée au dépôt et à la diffusion de documents scientifiques de niveau recherche, publiés ou non, émanant des établissements d'enseignement et de recherche français ou étrangers, des laboratoires publics ou privés. 


\title{
The results of 10 years of daily observations of the flux of suspended matter in one of the main water courses in the European Alps: the Isère at Grenoble (France)
}

\author{
Bilan de 10 années d'observations quotidiennes des flux de matière en suspension d'un \\ des principaux cours d'eau alpins : l'Isère à Grenoble (France)
}

Dominique Dumas, Institut de Géographie Alpine, Univ. Joseph-Fourier, 14 bis, av. MarieReynoard, 38100 Grenoble, France dominique.dumas@ujf-grenoble.fr

\begin{abstract}
:
Despite being only a medium-sized tributary of the Rhône, contributing on average $11 \%$ of the latter's annual flow, the Isère River nevertheless plays a major role in the Rhône's flux of suspended matter (SM). However, the transit of suspended matter down the Isère has been little studied. Based on regular and continuous observations between January 1995 and December 2005, the aims of this study were to quantify the flux of the Isère ai Grenoble, and to evaluate the monthly evolution of sedimentary transit since 1960. Mean annual flux over the last

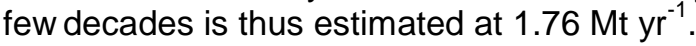

Key words: Alps; Isère drainage basin; sedimentary flux; evolution; France

\section{Résumé :}

Si l'Isère est un affluent relativement modeste du Rhône par sa contribution aux écoulements ( $11 \%$ en moyenne de l'écoulement annuel du Rhône), elle joue cependant un rôle essentiel dans les flux de matières en suspension (MES) de ce fleuve. Pour autant, le transit de matières en suspension de l'Isère reste encore l'objet de très peu d'études. A partir de relevés réguliers et continus, depuis janvier 1995 jusqu'à décembre 2005, l'objectif de cette étude est donc de quantifier les flux de l'Isère à Grenoble, et d'apprécier, au pas de temps mensuel, l'évolution de ces transits sédimentaires depuis 1960. Pour ces dernières décennies, le flux annuel moyen est ainsi évalué à $1.76 \mathrm{Mt} \mathrm{an}^{-1}$.

Mots-clés : Alpes ; bassin versant de l'Isère moyenne ; flux sédimentaire ; évolution ; France

\section{Introduction}

The Isère is a particularly good indicator of the hydro-sedimentary functioning of a large Alpine drainage basin. Although it is only a medium-sized tributary of the Rhône in terms of its contribution to the latter's volume, the Isère nevertheless plays an important role in the Rhône's flux of suspended and dissolved matter. However, there have been very few studies of the transit of suspended matter in the Isère, and certain quantifications and estimations of solid flow rates at Grenoble, where the basin has an area of $5720 \mathrm{~km}^{2}$, are still sometimes based on Pardé's 1925 estimation of $19.9 \mathrm{Mt} \mathrm{yr}^{-1}$ [24], itself calculated from the observations of Müntz and Lainé [22, 23]. Nearly twenty years later, Pardé [25] concluded that his own original evaluation

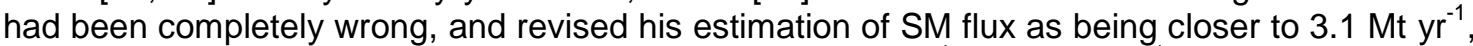
before publishing a new estimation of between 4 and $6 \mathrm{Mt} \mathrm{yr}^{-1}$ in 1964 [26] ${ }^{1}$. Recent attempts to assess sedimentary flux by Vautier [38] and Allain Jegou [2] clearly show the lack of information on the transit of suspended matter in the Isère.

However, managing a water course requires an accurate, up-to-date quantification of fluxes in order to assess the potential amount and rate of sedimentation, as the latter are factors in

\footnotetext{
1 The figures for total annual tonnes are taken for purposes of comparison from data given by various authors for the Isère at Grenoble; the figures for specific flux will be used later to compare different drainage basins.
} 
elevating a riverbed's level, thus directly impacting on the protection provided by embankments. The aims of the present study were therefore to quantify the flux of the Isère at Grenoble and to evaluate the evolution of sedimentary transit since 1960. To this end, regular and continuous measurements were made between January 1995 and December 2005.

The drainage basin under consideration, upstream from Grenoble, covers an area of $5720 \mathrm{~km}^{2}$ in the Northern Alps (Figure 1). The Isère is mainly fed by snow and rain, with high water levels from May till July, characteristic of a mountainous catchment area, more than $70 \%$ of which is above an altitude of $1000 \mathrm{~m}$. The mean annual flow of the Isère is $183 \mathrm{~m}^{3} \mathrm{sec}^{-1}$ over the reference period of 46 years beginning in 1960, when the hydrological station used in this study was opened) (Diren, Banque Hydro: W1410010). The last century was a relatively quiet one for the Isère, since the highest recorded flow rates scarcely reached half the maximum $2000 \mathrm{~m}^{3}$ $\mathrm{sec}^{-1}$ observed during the last great flood in 1859 [11]. The ten-year extreme event is generally estimated at around $760 \mathrm{~m}^{3} \mathrm{sec}^{-1}$, the fifty-year event at $1000 \mathrm{~m}^{3} \mathrm{sec}^{-1}$, and the hundred-year event at over $1600 \mathrm{~m}^{3} \mathrm{sec}^{-1}$ [38, Banque Hydro - Diren]; other studies have given slightly higher figures $[2,40]$.

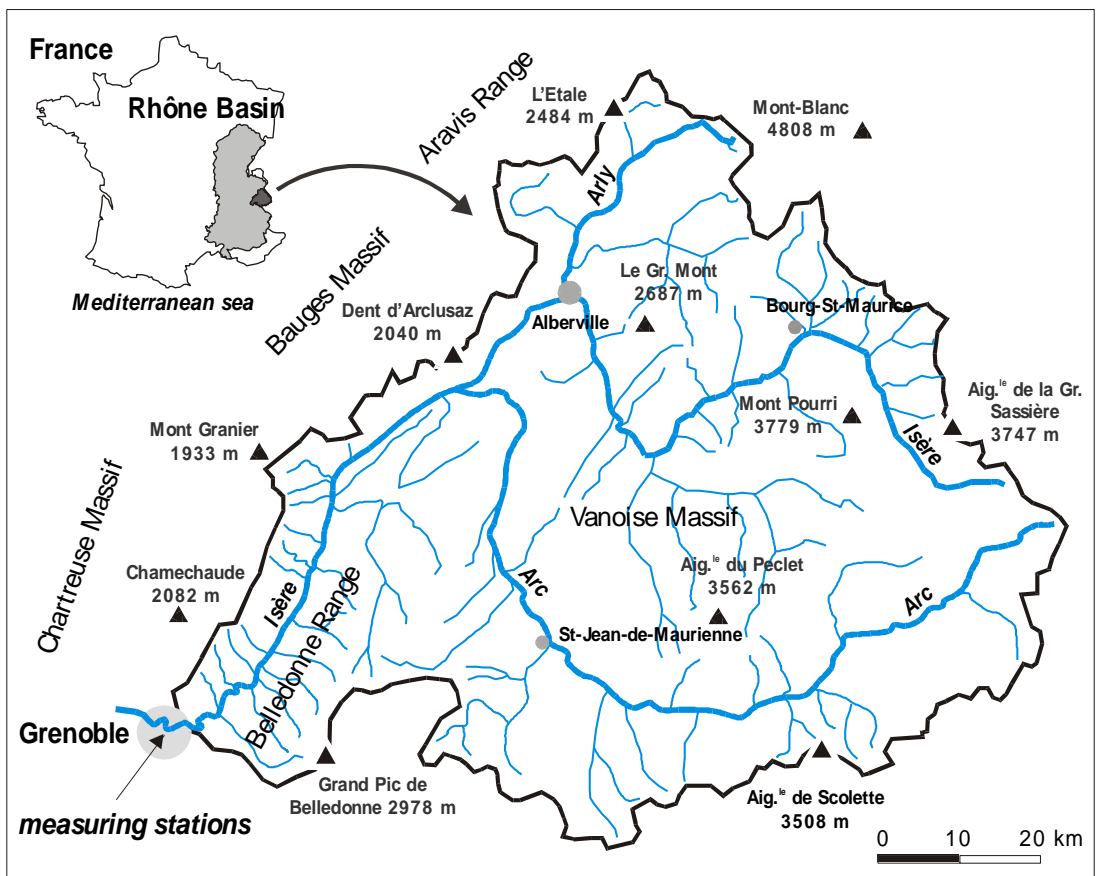

Figure 1. The Isère drainage basin at Grenoble.

Figure 1. Bassin versant de l'Isère à Grenoble

\section{Method}

Beginning in 1994, equipment allowing the flux of dissolved and suspended matter (SM) to be observed was progressively set up at the hydrometric station run by the Institut National Polytechnique de Grenoble (INPG) on Grenoble University Campus [28].

An automatic sampler on the left bank enabled SM concentrations to be measured from $500 \mathrm{ml}$ samples; the measurements were carried out by filtering with $0.45 \mu \mathrm{m}$ membranes and weighing. Measurements were made twice-daily from 1995 to 2004, then daily from January 2005 onwards. They were carried out by J.L. Peiry from 1995 to September 1999 [28], and by the present author since that time. The regularity of sampling and the high number of samples analysed, over 7200 in all, enabled daily SM fluxes to be worked out fairly accurately and monthly and yearly figures to be calculated with a reasonable degree of confidence.

Two turbidity gauge (Partech IR40C et IR15C) enabled certain missing data to be completed. However, the concentrations they measured sometimes showed sharp turbidity peaks due to the smearing or severe clogging of the gauges' optical systems. Such errors cannot yet be completely eliminated by new systems equipped with wipers and which were tested for a short time in the Isère. Studies of sedimentary transit in the Rhône have made the same observations [4]. Although such artificial peaks can be quite easily discerned, the relationship between sampling data and turbidity gauge data is sometimes poorly correlated due to the interference 
of texture, colour and undoubtedly various degrees of sediment aggregation, with the optical measurements $[13,15,31]$. This, plus the fact that the relationships between concentrations obtained from optical measurement and those from samples taken over short periods remain significant, is the reason why turbidity measurements have been used here simply to fill out incomplete data.

Along with constant measuring, over fifteen full gaugings were carried out, enabling the selective measurements to be compared to the actual mean concentrations of the wet-area cross-section. They were done with Isère flow rates recording between $105 \mathrm{~m}^{3} \sec ^{-1}(10$ October 2002) and $348 \mathrm{~m}^{3} \mathrm{sec}^{-1}$ (17 May 2001). The hydrological conditions corresponding to these gaugings (dates, flow rates, etc.) were described in a previous article [10]. In order to assess the evolution sedimentary transit over several decades, data from the hydrological station located a little way downstream from the Grenoble-Campus station (1960 - 2005: Diren $W$ 1410010) were used in the present study. However, the choice of this downstream station, where no full gauging has yet been carried out, made it necessary to resort to the method of estimating the mean concentration $(\mathrm{Cm})$ over the whole cross-section, based on the sampled concentration $\left(\mathrm{SM}_{\mathrm{fixed}}\right)$, and the following regressive model [10, Equation 1]:

$\mathrm{Cm}=0.832 \mathrm{SM}_{\mathrm{fixed}}+18.46 \quad \mathrm{R}^{2}=0.94$ (Equation 1)

The mean daily corrected concentration was then calculated from the two daily samples $(\mathrm{Cmd}$, in $\mathrm{mg}_{\text {litre }}{ }^{-1}$ ).

\section{Results}

\subsection{Anthropogenic impacts on the quantification of SM flux}

In their estimations of sedimentary transit, studies based on regular sampling, or a fortiori based on the extrapolation of limited measurements with $S M=f(Q)$ relationships, seldom highlight bias due to certain human activities directly affecting the water course (maintenance, the consolidation of riverbanks, development projects, etc.). Such short-term activities are fundamentally different from structural modifications of the river basin directly or indirectly linked to more permanent types of human activity such as deforestation, reafforestation, fire, land use changes, agriculture, urbanisation, etc., which often lead to long-term variations in sedimentary flux, and whose cause or causes can be both understood and evaluated [20,44].

Desperate attempts to identify relationships between concentrations, SM flux and liquid flow rates seem hardly worthwhile when such impacts become primordial with respect to the sedimentary transit of a water course. From January 2005 to July 2006, the Isère was thus subjected to major development work on its flood-banks about one km upriver from where this study's samples were taken, on the territory of the town of Gières. This had a significant effect on measurements, as the work resulted in considerable discharges of sediments over about $2300 \mathrm{~m}$ with the building of a temporary track at the foot of the flood-bank. The track was made from gravel and silt scooped directly from the riverbed. The highest mean daily concentration (Cmd) since the sampling instruments were set up was thus recorded on 18 April 2005, with an average of over $15.5 \mathrm{~g} \mathrm{~L}^{-1}$ for the sector. The same year, observed sedimentary flux was for the most part a direct result of anthropogenic disturbance, giving an annual transit some $7.5 \mathrm{Mt}$ higher than what would have normally been expected (see Table 2).

To a lesser degree, work on building the Maurienne motorway in the Arc River valley, begun in 1994, involved the consolidation of embankments and the building of civil engineering structures (in particular the Aiton, Saint André and Escalade viaducts), and interfered with the assessment of daily sedimentary flux. This was especially true in 1994 and throughout 1995 , when the work was mainly taking place in the area downiver from the Arc Valley, not far from its confluence with the Isère. In 1995 the recorded sedimentary flux was a great deal over the "normal", most likely more than $2.5 \mathrm{Mt}$ in comparison with an annual transit undisturbed by human activity (see Table 2). 


\subsection{Seasonal sedimentary variations}

For the above reasons, and in order show the Isère's monthly characteristics as well as its seasonal SM transport model [20], the years 1995 and 2005 have been eliminated from the monthly and yearly statistics (Table 1). For the period from 1996 to 2004, the means, deciles and medians of concentration, as well as the mean flux, calculated from the daily figures, give a good indication of the Isère's sedimentary transport model (Table 1).

Seasonal variations in sedimentary flux are in relative agreement with the rain-snow regime of the Isère. If the concentration model shows up in the means (monthly variation index: 4.2), it becomes even clearer in the upper deciles, where the monthly differences are greater (monthly variation index: 5.9). In contrast, the mean specific flux, with a peak in May and a lesser one in March, is less characteristic of seasonal variations, as it depends too much on sedimentary transfers linked to rising water levels. The maximum specific solid flow rate, for example, directly linked to rising-water periods, accounts for $47 \%$ of the variation in mean monthly solid flow, whereas deciles and medians are independent of such extremes. It is clear that days with a flux of around $63 \mathrm{t} \mathrm{km}^{2} \mathrm{~d}^{-1}$ (in one single day, 14 January 2004, a flux equivalent to 23,000 t $\mathrm{km}^{2} \mathrm{yr}^{-1}$ was recorded) will certainly have an influence on monthly means.

Table 1 Seasonal model of flow rates and SM transport de MES, $1996-2004$

Tableau 1 Régime saisonnier des débits et du transport de MES pour la période 1996 à 2004

\begin{tabular}{|c|c|c|c|c|c|c|c|c|c|c|c|}
\hline & \multirow{2}{*}{$\begin{array}{c}\text { Mean } Q \\
(\mathrm{~m} 3 / \mathrm{s})\end{array}$} & \multicolumn{4}{|c|}{ SM concentration (mg/L) } & \multirow{2}{*}{$\begin{array}{l}\text { Mean flux } \\
\text { (tonnes) }\end{array}$} & \multicolumn{5}{|c|}{ Specific flux $\left(T / \mathrm{km}^{2} /\right.$ day $)$} \\
\hline & & mean & $\mathrm{C} 10$ & $\mathrm{C} 50$ & c90 & & mean & C10 & $\mathrm{C} 50$ & c90 & $\max$ \\
\hline $\mathrm{J}$ & 141.2 & 125.0 & 29.8 & 62.4 & 162.5 & 91,481 & 0.516 & 0.05 & 0.13 & 0.44 & 62.97 \\
\hline $\mathrm{F}$ & 134.2 & 90.4 & 34.3 & 61.4 & 143.3 & 36,705 & 0.229 & 0.05 & 0.12 & 0.33 & 7.50 \\
\hline $\mathrm{M}$ & 161.5 & 244.6 & 37.9 & 79.6 & 337.6 & 208,566 & 1.176 & 0.06 & 0.18 & 1.06 & 52.46 \\
\hline A & 169.9 & 178.4 & 49.2 & 107.8 & 362.9 & 97,780 & 0.570 & 0.09 & 0.25 & 1.28 & 7.18 \\
\hline $\mathrm{M}$ & 265.4 & 367.1 & 69.2 & 185.2 & 848.6 & 366,330 & 2.066 & 0.19 & 0.62 & 5.07 & 39.57 \\
\hline $\mathrm{J}$ & 257.1 & 383.1 & 95.1 & 203.3 & 804.9 & 294,333 & 1.715 & 0.28 & 0.76 & 4.19 & 22.41 \\
\hline $\mathrm{J}$ & 180.9 & 199.5 & 71.0 & 124.0 & 323.1 & 113,220 & 0.639 & 0.14 & 0.32 & 1.07 & 26.89 \\
\hline A & 141.0 & 235.9 & 71.8 & 144.5 & 433.7 & 95,356 & 0.538 & 0.13 & 0.30 & 1.14 & 7.99 \\
\hline $\mathrm{s}$ & 125.5 & 169.6 & 61.4 & 123.5 & 256.1 & 57,486 & 0.335 & 0.10 & 0.24 & 0.63 & 6.13 \\
\hline 0 & 140.6 & 142.8 & 56.9 & 109.2 & 270.2 & 56,742 & 0.320 & 0.09 & 0.20 & 0.64 & 3.39 \\
\hline $\mathrm{N}$ & 147.9 & 135.6 & 46.2 & 86.5 & 254.8 & 52,510 & 0.306 & 0.07 & 0.17 & 0.71 & 2.52 \\
\hline D & 134.2 & 121.6 & 43.9 & 92.8 & 195.6 & 56,210 & 0.317 & 0.07 & 0.15 & 0.44 & 19.62 \\
\hline $\mathbf{Y}$ & 166.6 & 199.5 & 46.2 & 108.7 & 367.3 & $1,526,720$ & 0.731 & 0.08 & 0.24 & 1.25 & 62.97 \\
\hline
\end{tabular}

C10, C90, C50: deciles and medians of daily concentrations and specific daily SM flux. Like mean flux, they were calculated from mean daily data.

C10, C90, C50, : déciles et médianes des concentrations journalières et des flux spécifiques journaliers de MES. Comme le flux moyen, ils sont calculés à partir des données moyennes journalières.

Medians and (especially) upper deciles, less influenced by extreme events, themselves independent of the seasons (three major rises in the river level were observed in May, March and January respectively), seem the most pertinent factors to use in describing seasonal fluctuations of SM flux. They highlight the strong seasonal variations in sedimentary transit, superior to 15 (from 0.3 to $5.1 \mathrm{t} \mathrm{km}^{2}$ day $^{-1}$ ) for the upper deciles of specific flux (Table 1). The months of May and June clearly show the importance of snow melt in sedimentary production.

\subsection{The importance of periods of rising water in sedimentary transit}

As with most rivers $[21,29,36,37,42,43]$, the times at which the Isère rises are those accounting for most of its annual sedimentary transit. The evolution and quantities of suspended matter carried by the river during periods of rising water were closely monitored by means of twice-daily sampling. Since 1996, there have been three such periods at Grenoble with an expected occurrence of 10 years or slightly more: in May $1999\left(\mathrm{Qmax}=809 \mathrm{~m}^{3} \mathrm{sec}^{-1}\right)$, March $2001\left(\mathrm{Qmax}=875 \mathrm{~m}^{3} \mathrm{sec}^{-1}\right)$ and January $2004\left(\mathrm{Qmax}=750 \mathrm{~m}^{3} \mathrm{~s}^{-1}\right)$. With transits of over 1 million tonnes in ten days for the first two and half a million tonnes in four days for the third, these three episodes were typical examples of the importance of this type of event. They accounted for $34 \%, 39 \%$ et $30 \%$ respectively of the annual tonnage (equal to $3.2 \mathrm{Mt}$ in 1999 , 3.0 Mt in 2001 et $1.7 \mathrm{Mt}$ in 2004 ) for $1.3 \%, 5.4 \%$ et $3.3 \%$ of the annual water volumes carried by the river. Rising-water periods thus require fairly regular monitoring of SM and show that estimations of sediment transfer based on insufficient or insufficiently-frequent sampling may be somewhat unreliable. 
Duration curves [21] show how important rising-water periods are and enable the Isère's sedimentary variations to be more accurately discerned (Fig. 2). Apart from 1995 and 2005, the curves are all fairly similar, and can be superimposed on each other, with all of them remaining within the delineations of 2000 and 2004 (Fig. 2). Over half the Isère's annual sedimentary transit (from $44 \%$ to $71 \%$, depending on the year; $55 \%$ on average) is generally transported within a lapse of 30 days, i.e. about $8 \%$ of the year. These figures partially agree with, and complete, Meybeck's estimations for the Rhône-Alpine area [20]. The curves also show that 1995 and 2005 were anomalous years, and thus provide an additional means of detecting the possibility of transit having been significantly influenced by work along river banks or in their immediate vicinity.

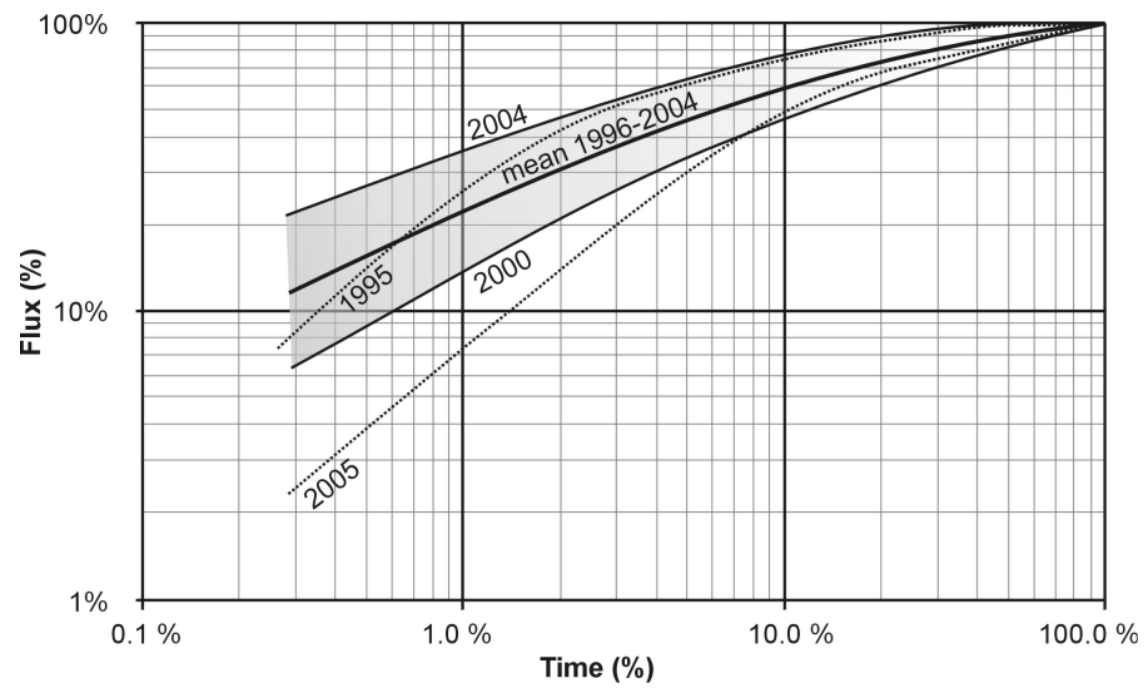

Figure 2. Annual duration curves: the length of time in percent needed to carry away a quantity of annual sedimentary flux. Anomalousness of 1995 and 2005

Figure 2. Courbes de durée annuelle : pourcentage du temps nécessaire pour évacuer une quantité de flux sédimentaire annuel. Singularité des années 1995 et 2005

\subsection{The relationship between SM flux and water flows, and estimation of flux since 1960}

In order to make up for incomplete data (September - December 1998) and be able to estimate sedimentary transits over a longer period of time, a relationship between SM flux and the flow rate of water needs to be established. Relationships such as $S M=a^{b}$, although regularly used in many studies [3, 5, 12, 20,29], are poorly demonstrated (with a few exceptions) by daily data from the Isère, even if attempts are made to do so on a monthly or seasonal basis. The oftenclockwise hysteresis of rising-water events is the main explanation for this, as sediments deposited during the previous such event go back into suspension when water level next rises $[20,37,42]$. Setting aside rising-water events, the use of regular, frequent sampling can lead to a large number of different cases, various types of high-water hysteresis, and differing pre-rise basin conditions. Irregular relationships between daily concentrations and observed flow rates are therefore hardly surprising when they concern a relatively large drainage basin located, moreover, in a high-mountain area, where processes of sedimentary supply, contributory zones and pre-flood basin conditions may vary considerably over time and are even partly independent of seasonal influence.

In contrast, taken month by month, mean concentrations and, to an even greater degree, solid monthly flux (Qsm in tonnes month $\left.{ }^{-1}\right)$ are quite well related to monthly liquid flow $\left(\mathrm{Qm}\right.$, in $\mathrm{m}^{3}$ $\left.\mathrm{sec}^{-1}\right)$; this is also usually given in the form of a power equation $\mathrm{Qs}=\mathrm{a} \mathrm{m^{b }}[3,29,30]$. The relationship used for the Isère gives the following (Equation 2: Fig. 3):

Qsm =0.7446 Qm ${ }^{2.269}$ (Equation 2)

$=0.81$

The year 1995, despite improving the explanation of the model very slightly $(r=0.82)$, has been excluded. On the other hand, Figure 3 clearly shows and confirms the influence of the work on the Isère embankments in 2005 , with monthly figures for sedimentary transit which are clearly 
different from other years. The relationship has thus been established from the $1996-2004$ period and explains around $66 \%$ of the variation in the Isère's monthly sedimentary flux. Months where water levels rise significantly, resulting in heavy transport, are nevertheless still underestimated. Such under-estimation of transit is often unavoidable, even with strictly daily models, when high-water events have not been measured [3, 4, 29]. According to Equation 1, underestimation of monthly figures is around $1 \mathrm{Mt}$ for the rising-water events of May 1999 and March 2001, and around $0.5 \mathrm{Mt}$ for that of January 2004.

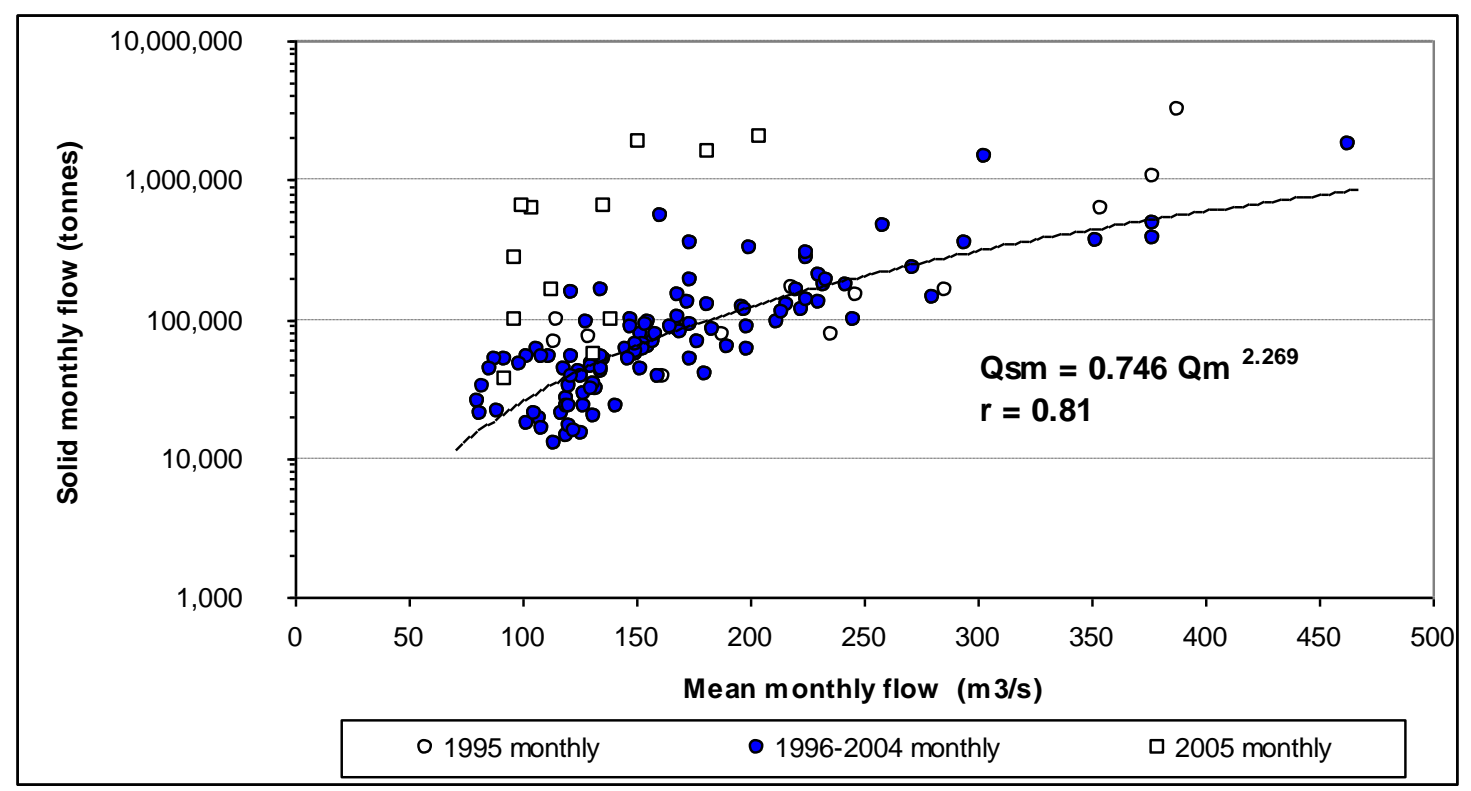

Figure 3. Relationship between solid (Qsm) and liquid (Qm) monthly flow. Reference period: 1996-2004.

Figure 3. Relation entre les débits solides mensuels (Qsm) et liquides (Qm). Période de référence : 1996-2004.

Since the monthly figures described above take little account of periods of during which the river rose to very high levels, it seems worthwhile to attempt to complete the present estimations of monthly transit by including days of very high flow rates. During flood periods from 1996 to 2004, power relationships, with daily flux and flow rates, are better shown than for the rest of the time, especially for flow rates in excess of $500 \mathrm{~m}^{3} \mathrm{sec}^{-1}\left(r^{2}=0.65\right.$, with figures for 16 days, Equation 2), and steadily decline if flow-rate thresholds of over $450 \mathrm{~m}^{3} \mathrm{sec}^{-1}\left(\mathrm{r}^{2}=0.52\right.$ with records for 36 days) or $400 \mathrm{~m}^{3} \mathrm{sec}^{-1}$ ( $\mathrm{r}^{2}=0.49$, with 60 days) are used instead. For days where the daily flow rate is over $500 \mathrm{~m}^{3} \mathrm{sec}^{-1}$, daily transit can be shown by the following (Equation 3):

Qsd $=2.53610^{-7} \mathrm{Qd}^{4.191}$, with Qsd en $\mathrm{t} \mathrm{d}^{-1} \quad$ (Equation 3)

$r=0.81$

Strictly speaking, basic monthly transit (Qsm, Equation 2) including daily flow rates over $500 \mathrm{~m}^{3}$ $\sec ^{-1}$ only should be estimated on the basis of a new monthly flow rate. This approach has not been adopted, however, as its effect on final results is minimal, and it unnecessarily and probably deceptively complicates estimations of transit. For the three years in which a major rising-water event was observed, taking the sedimentary transit of episodes over $500 \mathrm{~m}^{3} \mathrm{sec}^{1}$ into account raised estimations of annual transit from 2.2 Mt to 3.1 Mt in 1999 (3.2 Mt were estimated from measurements), from 2.3 Mt to $2.9 \mathrm{Mt}$ in 2001 (3.0 Mt measured) and from 0.8 Mt to $1.0 \mathrm{Mt}$ in 2004 (1.7 Mt measured).

Overall, for the period between 1996 and 2004, taking into account, if only partially, such risingwater events over the threshold of $500 \mathrm{~m}^{3} \mathrm{sec}^{-1}$ thus clearly improves the accuracy of final estimations of monthly sedimentary transit. The relationship between calculation and measurement of flux is improved, with a Bravais-Pearson coefficient of 0.82 instead of 0.62 , when an estimation does not include daily flows of $500 \mathrm{~m}^{3} \mathrm{sec}^{-1}$. The period for which data are missing, from September to December 1998, can thus be reconstituted in monthly stages with 
certain degree of confidence in as much as the Isère was generally fairly low during that time. For the years measured, apart from 1995 and 2005, annual SM flux ranged from 0.89 to 3.16

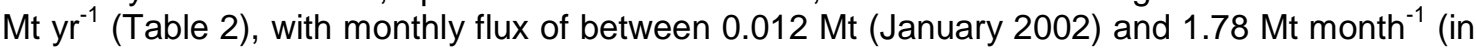
May 1999).

As reconstituted since 1960, fluctuations of monthly and annual flux have increased slightly in amplitude, while remaining within the same general scale of values. Thus, over the 46-year period studied, monthly flux varied by a ratio of $1: 333$, compared with a ratio of about $1: 13$ for annual flux. These ratios naturally reflect the importance of rising-water events for sedimentary transit, but above all indicate considerable seasonal variations, intra-annual fluctuations being considerably greater than inter-annual ones.

Table 2. Estimation of annual SM flux of the Isère at Grenoble since 1960, with Q : annual mean flow $\left(\mathrm{m}^{3} \mathrm{sec}^{-1}\right)$, estimated flux with monthly flow (Qsm), and with monthly flow plus daily high-water flow $>500 \mathrm{~m}^{3} \mathrm{~s}^{-1}(\mathrm{Qsm}+Q \mathrm{sd})$, and measured flux between 1995 and 2005. All SM flux in $10^{6}$ tonnes.

Tableau 2. Estimation des flux de MES annuels de l'Isère à Grenoble depuis 1960, avec ; Q: module annuel $\left(\mathrm{m}^{3} \mathrm{~s}^{-1}\right)$, flux estimé avec les débits mensuels (Qsm), et avec les débits mensuels plus les crues journalières supérieures à $500 \mathrm{~m}^{3} \mathrm{~s}^{-1}$ (Qsm+Qsj), et flux mesuré entre 1995 et 2005. Tous ces flux de MES sont en $10^{6}$ tonnes.

\begin{tabular}{|c|c|c|c|c|c|c|c|c|c|c|c|c|}
\hline Yr & $\mathbf{Q}$ & $\begin{array}{l}\text { Estim } \\
\text { with } \\
\text { Qsm }\end{array}$ & $\begin{array}{c}\text { ated flux } \\
\text { with Qsm } \\
+ \text { Qsd }\end{array}$ & Yr & $\mathbf{Q}$ & $\begin{array}{l}\text { Estim } \\
\text { with } \\
\text { Qsm }\end{array}$ & $\begin{array}{l}\text { ted flux } \\
\text { with Qsm } \\
+ \text { Qsd }\end{array}$ & Yr & $\mathbf{Q}$ & $\begin{array}{l}\text { Estim } \\
\text { with } \\
\text { Qsm }\end{array}$ & $\begin{array}{l}\text { ted flux } \\
\text { with Qsm } \\
+ \text { Qsd }\end{array}$ & $\begin{array}{l}\text { Measured } \\
\text { flux }\end{array}$ \\
\hline 1960 & 186 & 1.4 & 1.4 & 1976 & 111 & 0.4 & 0.4 & 1992 & 193 & 1.6 & 2.0 & - \\
\hline 1961 & 176 & 1.2 & 1.4 & 1977 & 224 & 2.2 & 2.2 & 1993 & 178 & 1.2 & 1.2 & - \\
\hline 1962 & 166 & 1.2 & 1.2 & 1978 & 234 & 2.5 & 3.3 & 1994 & 219 & 2.1 & 2.2 & - \\
\hline 1963 & 185 & 1.6 & 2.0 & 1979 & 210 & 1.9 & 1.9 & 1995 & 235 & 2.7 & 3.1 & 5.7 \\
\hline 1964 & 117 & 0.5 & 0.5 & 1980 & 241 & 2.7 & 3.4 & 1996 & 145 & 0.8 & 0.8 & 1.1 \\
\hline 1965 & 176 & 1.3 & 1.3 & 1981 & 252 & 2.7 & 2.9 & 1997 & 148 & 0.9 & 0.9 & 0.9 \\
\hline 1966 & 234 & 2.9 & 4.7 & 1982 & 234 & 2.3 & 2.7 & 1998 & 158 & 1.0 & 1.0 & 1.0 \\
\hline 1967 & 181 & 1.4 & 1.6 & 1983 & 237 & 2.6 & 4.1 & 1999 & 213 & 2.2 & 3.1 & 3.2 \\
\hline 1968 & 173 & 1.2 & 1.3 & 1984 & 193 & 1.4 & 1.4 & 2000 & 168 & 1.1 & 1.3 & 1.2 \\
\hline 1969 & 162 & 1.1 & 1.1 & 1985 & 205 & 1.6 & 1.6 & 2001 & 217 & 2.3 & 2.9 & 3.0 \\
\hline 1970 & 219 & 2.8 & 5.2 & 1986 & 198 & 1.6 & 1.6 & 2002 & 163 & 1.0 & 1.0 & 0.9 \\
\hline 1971 & 132 & 0.6 & 0.6 & 1987 & 217 & 2.1 & 2.4 & 2003 & 147 & 0.9 & 0.9 & 1.0 \\
\hline 1972 & 133 & 0.6 & 0.6 & 1988 & 221 & 2.1 & 2.1 & 2004 & 140 & 0.8 & 1.0 & 1.7 \\
\hline 1973 & 149 & 0.9 & 1.1 & 1989 & 122 & 0.6 & 0.6 & 2005 & 129 & 0.6 & 0.6 & 8.1 \\
\hline 1974 & 156 & 0.9 & 0.9 & 1990 & 158 & 1.0 & 1.2 & & & & & \\
\hline 1975 & 189 & 1.5 & 1.5 & 1991 & 156 & 0.9 & 1.0 & Mean & 183 & 1.49 & 1.76 & 1.54 \\
\hline
\end{tabular}

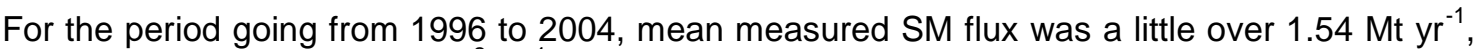
i.e. a specific flux of $270 \mathrm{t} \mathrm{km}^{-2} \mathrm{yr}^{-1}$. The period studied nevertheless shows a mean model for the Isère slightly lower $\left(167 \mathrm{~m}^{3} \mathrm{sec}^{-1}\right)$ than the one calculated over 46 years $\left(183 \mathrm{~m}^{3} \mathrm{sec}^{-1}\right)$. Over the period from 1960 to 2005 (Fig. 4), mean SM export by the Isère, according to the estimations derived from reconstitutions (Qsm + Qsd), amounted to $1.76 \mathrm{Mt} \mathrm{yr}^{-1}$, i.e. a specific flux of $308 \mathrm{t} \mathrm{km}^{-2} \mathrm{yr}^{-1}$. Based on a larger number of samples and figures for sedimentary flux given in monthly steps over 46 years, this mean figure thus gives a more accurate revised estimation than that of $2.20 \mathrm{Mt} \mathrm{yr}^{-1}$ reached in a previous study [10]. 


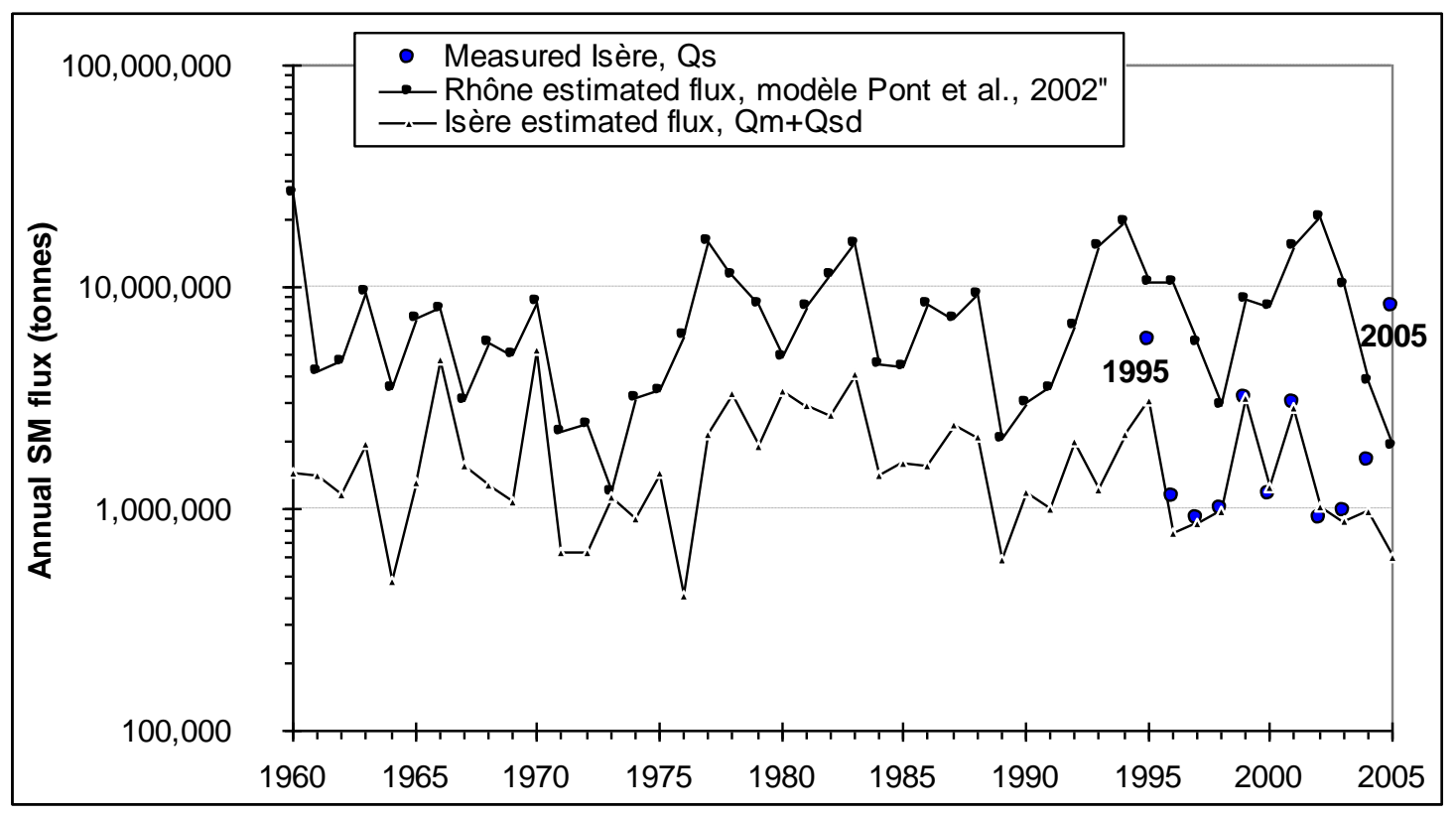

Figure 4. Evolution of annual sedimentary flux in the Isère (measured and calculated), and in the Rhône, estimated from the model of Pont et al., 2002.

Figure 4. Évolution des flux sédimentaires annuels de l'lsère (mesurés et calculés) et ceux du Rhône, estimés avec le modèle de Pont et al., 2002.

When solid flow rates of the Isère and the mouth of the Rhône are compared, on the basis of a reconstitution of the Rhône's using the model by Pont et al. [29], both rivers show fairly similar annual transit variations (Fig. 4). From 1960 to 2005, the Isère contributed an average of around $11 \%$ of the volume of the Rhône's annual flow as measured at Beaucaire, but an average of nearly a quarter of the Rhône's annual sedimentary transit. However, the latter figure hides considerable inter-annual variations on the one hand and a clear tendency on the other towards a drop in the Isère's contribution to the Rhône's SM sedimentary transit, with an average of $35 \%$ in the early 1960 s, compared with an average of $22 \%$ at the beginning of the $21^{\text {st }}$ century.

\section{Comparisons with other Alpine rivers and streams}

The specific annual flux of the Isère, calculated at around $310 \mathrm{t} \mathrm{km}^{-2} \mathrm{yr}^{-1}$, does not show the extent to which its sedimentary inputs are actually spatially heterogeneous. The Arc supplies the Isère with its greatest quantities by far of SM, particularly via the former's own tributary, the Arvan [19]. The mean specific annual flux of the Arvan exceeds $2500 \mathrm{t} \mathrm{km}^{-2} \mathrm{yr}^{-1}$ for a steeplysloping basin of about $200 \mathrm{~km}^{2}$; at the confluence of the Arc and the Isère this drops to 766 $\mathrm{t} \mathrm{km}^{-2} \mathrm{yr}^{1}$ for a basin of almost $2000 \mathrm{~km}^{2}$ [19]. Such a difference is by no means unusual for a basin covering a large area [21], especially when a mountain region of considerable lithological complexity is involved, leading to the geographical diversity of sedimentary inputs. In the Isère river basin, the sector most favourable to sedimentary input is in fact the Maurienne Valley (through which the Arc flows) with its mostly-bare slopes and geological formations highly susceptible to erosion: Lias schist on the Arc's left bank (particularly the Arvan basin) and lustrous shale upstream from Modane. In the northern sector, the basins of the Tarentaise Valley (the upper Isère) appear less erodible due to more extensive plant cover, even where the geological formations are vulnerable ones [14]. Finally, basins located on external crystalline massifs (e.g. the Belledonne Range) are less vulnerable to erosion due to the geological formations' resistance and extensive plant cover.

The mean specific erosion rate of the Isère, lower than the Arc's, nevertheless comes well within the range of 250 to $350 \mathrm{t} \mathrm{km}^{-2} \mathrm{yr}^{-1}$ put forward for the eastern edge of the Pyrenees [36, 37], and significantly exceeds the European average of between 30 and $80 \mathrm{t} \mathrm{km}^{-2} \mathrm{yr}^{-1}[6,18]$. It fits the figures for a number of major mountain water courses whose basins drain comparable areas [21, 33, 34]. Examples from Switzerland include the Arve et Geneva $\left(299 \mathrm{t} \mathrm{km}^{-2} \mathrm{yr}^{-1}\right.$ for a 
basin of $\left.2079 \mathrm{~km}^{2}\right)$, the Alpine Rhône at Porte de Scex $\left(320 \mathrm{t} \mathrm{km}^{-2} \mathrm{yr}^{-1}\right.$ for a basin of $\left.5220 \mathrm{~km}^{2}\right)$, and the Alpine Rhine at Bad Ragaz (323 t km $\mathrm{yr}^{-1}$ for a basin of $\left.4455 \mathrm{~km}^{2}\right)$. The mean specific flux of the Isère is also comparable to (and in some years exceeds) that of the Durance, evaluated at $360 \mathrm{t} \mathrm{km}^{-2} \mathrm{yr}^{-1}$ [1], a river located in the Alpine Arc, but in a region under a much more Mediterranean influence.

Over the whole Alpine Arc, in fact, it is in small sectors and drainage basins of the most southerly parts (les Alpes du Sud), especially in areas of black marl, that the highest rates of erosion have been observed, usually ranging between 12,500 and $20,000 \mathrm{t} \mathrm{km}^{-2} \mathrm{yr}^{-1}$ [8]. In local areas figures can even exceed $60,000 \mathrm{t} \mathrm{km}^{-2} \mathrm{yr}^{-1}$ [17]. Such rates of erosion, as measured in the Alpes du Sud, are nevertheless a great deal lower in more extensive river basins. Studies of sedimentary silting at various dams [7, 9] have resulted in erosion figures of $2500 \mathrm{t} \mathrm{km}^{-2} \mathrm{yr}^{-1}$ for Claps Dam (with a basin of $182 \mathrm{~km}^{2}$ ), $900 \mathrm{t} \mathrm{km}^{-2} \mathrm{yr}^{-1}$ for L'Escale Dam (with a basin of 3500 $\mathrm{km}^{2}$ ), $414 \mathrm{t} \mathrm{km}^{-2} \mathrm{yr}^{-1}$ for Serre-Ponçon Dam (with a basin covering $3000 \mathrm{~km}^{2}$ ), and $90 \mathrm{t} \mathrm{km}^{-2} \mathrm{yr}^{-1}$ for Cadarache Dam (a basin of $5500 \mathrm{~km}^{2}$ ). Such high spatial variations of specific erosion are also found in the Northern Alps [7, 9, 41], where sedimentary silting of dams shows the following rates of erosion: $670 \mathrm{t} \mathrm{km}^{-2} \mathrm{yr}^{-1}$ at Sautet Dam (for a basin of $1000 \mathrm{~km}^{2}$ ), $490 \mathrm{t} \mathrm{km}^{-2} \mathrm{yr}^{-1}$ at Verney Dam (for a basin of $120 \mathrm{~km}^{2}$ ), $220 \mathrm{t} \mathrm{km}^{-2} \mathrm{yr}^{-1}$ at Chambon Dam (for a basin of 220 $\mathrm{km}^{2}$ ), even going as low as $90 \mathrm{t} \mathrm{km}^{-2} \mathrm{yr}^{-1}$ at Aussois Dam (for a basin of $150 \mathrm{~km}^{2}$ ). Such spatial variability of erosion can also be found over the whole of a water course itself; it has been described in the north-west of Italy, for example, for the Dora Baltea, an Alpine tributary of the Po River. Sedimentary transport of SM is higher in the upper part of the basin and diminishes going downstream, with specific erosion figures of $553 \mathrm{t} \mathrm{km}^{-2} \mathrm{yr}^{-1}$ for a basin of $543 \mathrm{~km}^{2}, 265$ $\mathrm{t} \mathrm{km}^{-2} \mathrm{yr}^{-1}$ further downstream for a basin of $1303 \mathrm{~km}^{2}$, and $181 \mathrm{t} \mathrm{km}^{-2} \mathrm{yr}^{-1}$ for a basin of 3264 $\mathrm{km}^{2}$ [39].

Even when confined within the Alpine Arc, however, comparisons are difficult to make properly, as local characteristics specific to each basin have a strong influence on the intensity of sedimentary flux. Basin size is one important explanatory factor, but definitely not the only one. Studies of the sedimentary silting of Alpine dams have moreover partly highlighted this complexity (see above). The Alpine Rhine at Lustenau (Austria) is an extremely good example, since specific annual SM flux exceeds $1800 \mathrm{t} \mathrm{km}^{-2} \mathrm{yr}^{-1}$ there, despite a basin covering an area of over $6000 \mathrm{~km}^{2}$ [21]. Conversely the mean annual flux of the Glatt, observed at Rheinfelden in Switzerland, is $8 \mathrm{t} \mathrm{km}^{-2} \mathrm{yr}^{-1}$ for a basin of $416 \mathrm{~km}^{2}$ [34]. Similarly, in the Alps of north-eastern Italy the Rio Cordon, with a basin of $5 \mathrm{~km}^{2}$, has a mean specific erosion of only $69 \mathrm{t} \mathrm{km}^{-2} \mathrm{yr}^{-1}$ [16]. A study of SM flux in over a score of Swiss Alpine water courses has clearly shown that flux is independent of the area of a drainage basin, and that there is considerable geographical variation in figures, ranging from 8 to over $1500 \mathrm{t} \mathrm{km}^{-2} \mathrm{yr}^{-1}$ for basins covering areas of between 350 and $1500 \mathrm{~km}^{2}$ [34]. Comparisons must also be treated with a great deal of circumspection when authors do not give annual means. When, as is frequently the case, inter-annual variations of SM flux are high, such comparisons are actually meaningless. In the Bavarian Alps of Germany, two confluents of the Donau have annual rates of erosion ranging respectively from 2 to $86 \mathrm{t} \mathrm{km}^{-2} \mathrm{yr}^{-1}$ for the Partnach, and from 180 to $1500 \mathrm{t} \mathrm{km}^{-2} \mathrm{yr}^{-1}$ for the Lahnenwiesgraben [35].

In addition to the information outlined herein and the model of SM flux defined (potentially enabling easier future management of the Isère's sediments), the present study's analysis of the Isère's sedimentary transit, reconstituted for the last four decades, has resulted in a reliable, representative mean figure of sedimentary flux, and thereby made a valuable contribution to a yet-to-be-made synthesis of sedimentary flux on the scale of the whole Alpine area.

\section{Conclusion}

Downriver from Grenoble, the Isère no longer seems to export river-bottom sediments [27, 32, 38]. The large number of obstacles built in the beds of the different water courses undoubtedly hinder the transport of solids, to the extent that there are probably no longer any large-sized materials reaching the confluence of the Drac and the Isère. On the other hand, the transit of suspended sediments in the Isère, with a mean annual flux estimated $1.76 \mathrm{Mt} \mathrm{yr}^{-1}$ over recent decades, remains at significant levels.

The contribution of extrapolation to all estimations of sedimentary transit is still, and will probably long remain, a considerable one in this type of evaluation. Concerning the Isère, this is 
evidenced, moreover, by Pardé's series of estimations [24, 25, 26], hence the need to specify the sources and methods of evaluation used (measurements or other, the number of samples, figures estimated from a model, etc.) and to link the latter to the figures given. The results presented are the first to have been established for the flux of suspended matter in an important Alpine water course. There are still very few continuous, decade-long data available for the Alps. On the scale of the Isère basin, annual and monthly sedimentary flux is obviously heavily dependent on water volumes. Nevertheless, rising-water periods, during which a significant proportion of annual solid flow is transported, upsets these relationships. In consequence, it would be interesting to improve current knowledge of monthly flux, reached by default, by making further estimations on a daily basis of sedimentary transit produced by such hydrological incidents.

\section{Acknowledgements}

The author wishes to thank J.-L. Peiry (professor at the University of Clermont-Ferrand) for having provided part of the equipment for measuring SM at Grenoble-Campus station; P. Bois (professor at the INPG) and the INPG for permitting access to the Campus hydrological station. The author also extends his thanks to the two anonymous reviewers for their remarks and comments.

\section{Références}

[1] C. Alary, Mécanismes et bilans d'érosion dans un bassin versant méditerranéen aménagé : le cas de la Durance (S-E France). PhD thesis, Univ. d'Aix-Marseille, 1998 (275 p.).

[2] C. Allain Jegou, Relations végétation, écoulement, transport solide dans le lit des rivières; étude de l'Isère dans le Grésivaudan. PhD thesis, Inst. Nat. Polytech. de Grenoble, specialised in Geophysical and Environmental Mechanics, 2002 (198 p.).

[3] C. Antonelli, Flux sédimentaires et morphogenèse récente dans le chenal du Rhône aval. PhD thesis, Univ. d'Aix-Marseille I, 2002 (272 p.).

[4] C. Antonelli, Représentativité des flux de radioactivité mesurés par la station-observatoire du Rhône (station d'Arles, réseau OPERA). IRSN, Service d'étude et de la surveillance de la radioactivité dans l'environnement, rapport DEI-SESUR, 2004 (23 p.).

[5] J.-P. Bravard, F. Petit, Les cours d'eau. Dynamique du système fluvial, Armand Colin, Masson, 1997 (221 p.).

[6] M.B. Collins, Processes and controls involved in the transfer of fluviatile sediments to the deep ocean. J. Geol. Soc., London 143 (1986) 915-920.

[7] L. Descroix, E. Gautier, Water erosion in the southern French Alps: climatic and human mechanisms. Catena 50 (2002) 53-85.

[8] L. Descroix, J.-C. Olivry, Spatial and temporal factors of erosion by water of black marls in the badlands of the French southern Alps. Hydrological Sciences-J.-des Sciences Hydrologiques 47, 2, (2002) 227-242.

[9] L. Descroix, N. Mathys, Processes, spatio-temporal factors and measurements of current erosion in French Southern Alps : a review. Earth Surface Processes and Landforms 28 (2003) 993-1011.

[10] D. Dumas, Optimisation de la quantification des flux de matière en suspension d'un cours d'eau alpin : I'Isère à Grenoble (France). Comptes Rendus Geosciences Volume 336, Issue 13 (2004a) 1149-1159.

[11] D. Dumas. The two memorable floods on the Isère in Grenoble (1651 and 1859): An analysis of estimates by M. Pardé. Revue de Géographie Alpine, Journal of Alpine Research, n॰3 (2004b) 38-49.

[12] D. Eisma, Suspended matter in the aquatic environment, Springer-Verlag, Berlin, 1993 (315 p.).

[13] C.J. Gippel, Potentiel of turbidity monitoring for measuring the transport of suspended solids in streams. Hydrological Processes volume 9, 1 (1995) 83-97 
[14] C. Latulippe, J.-L. Peiry, Essai de hiérarchisation des zones de production de matière en suspension dans le bassin-versant d'un grand cours d'eau : l'Isère en amont de Grenoble. Rev. de Géographie Alpine, 2, 1996, 29-44.

[15] M.A. Lenzi, L. Marchi, Suspended sediment load during floods in a small stream of the Dolomites (northeastern Italy). Catena 39 (2000) 267-282.

[16] M.A. Lenzi, L. Mao, F. Comiti, Interannual variation of suspended sediment load and sediment yield in an alpine catchment. Hydrological Sciences-J.-des Sciences Hydrologiques 48, 6, (2003) 899-916.

[17] R. Lhénaff, P. Coulmeau, M. Lecompte, A. Marre, Erosion and transport processes on badlands slopes in the Baronnies mountains (French Southern Alps). Geografia Fisica e Dinâmica Quaternaria 16 (1993) 65-73.

[18] W. Ludwig, J.-L. Probst, River sediment discharge to the oceans: present-day controls and global budgets, Am. J. Sci 298 (1998) 265-295.

[19] A. Marnezy, L'Arc et sa vallée. Anthropisation et géodynamique d'une rivière alpine dans son bassin versant. State thesis, Univ. Joseph Fourier, Grenoble I, 1999 (682 p.).

[20] M. Meybeck, Transport et qualité des sédiments fluviaux : de la variabilité spatio-temporelle à la gestion. La Houille Blanche, 6-7 (2001) 34-43.

[21] M. Meybeck, L. Laroche, H.H. Dürr, J.P.M. Syvitski, Global variability of daily total suspended solids and their fluxes in rivers. Global and Planetary Change, 39 (2003) 65-93.

[22] A. Müntz, E. Lainé, Les matériaux charriés par les cours d'eau des Alpes et des Pyrénées, C. R. Acad. Sci. Paris 156 (1913) 848-851.

[23] A. Müntz, E. Lainé, Etudes sur la formation des limons et leurs charriages par les cours d'eau des Alpes et des Pyrénées, C. R. Acad. Sci. Paris 160 (1915) 462-467.

[24] M. Pardé, Le régime du Rhône. Étude hydrologique, in : Etudes et Travaux, Univ. de Lyon, Institut des Etudes rhodaniennes, 1925, republished 2004, Lyon, coll. Géocarrefour, 3 vol. (850 p.).

[25] M. Pardé, Quelques nouveautés sur le régime du Rhône, in : Mém. et Doc., vol. 1, Univ. de Lyon, Institut des études rhodaniennes, 1942, republished 2004, Lyon, coll. Géocarrefour. (139 p.).

[26] M. Pardé, Fleuves et rivières. Coll. Armand Colin, $n^{\circ} 155$, section de Géographie, 4th edition, 1964 (224 p.).

[27] J.-L. Peiry, P.-G. Salavador, F. Nougier, L'incision des rivières dans les Alpes du nord : état de la question. Rev. de Géographie de Lyon, vol. 69, 1994, 47-56.

[28] J.-L. Peiry, Recherches en géomorphologie fluviale dans les hydrosystèmes fluviaux des Alpes du Nord, IGA Habilitation, Univ. Joseph-Fourier, Grenoble-1, 1997 (308 p.).

[29] D. Pont, J.P. Simonnet, A.V. Walter, Medium-term changes in suspended sediment delivery to the ocean: consequences of catchment heterogeneity and river management (Rhône River, France). Estuar Coast Shelf S. 54 (2002), 1-18.

[30] E. Remy-Berzencovitch, Nouvelle méthode de calcul du débit solide des cours d'eau. Osterreichische Wasser-Wirtschaft (1959), 59-66.

[31] S. J. Riley, The sediment concentration-turbidity relation: its value in monitoring at Ranger Uranium Mine, Northern Territory, Australia. Catena 32, 1 (1998) 1-14.

[32] P.G. Salvador, Le thème de la métamorphose fluviale dans les plaines alluviales du Rhône et de l'Isère. PhD thesis, Univ. de Lyon III, 1991 (498 p.).

[33] F. Schlunegger, M. Hinderer, Crustal uplift in the Alps: why the drainage pattern matters. Terra Nova 13 (2001) 425-432.

[34] F. Schlunegger, M. Hinderer, Pleistocene/Holocene climate change, re-establishment of fluvial drainage network and increase in relief in the Swiss Alps. Terra Nova 15 (2003) 88-95. 
[35] K.-H. Schmidt, D. M. Morche, Sediment output and effective discharge in two small high mountain catchments in the Bavarian Alps, Germany. Geomorphology 80 (2006) 131-145.

[36] P. Serrat, Dynamique sédimentaire actuelle d'un système fluvial méditerranéen : I'Agly (France), C. R. Acad. Sci. Paris, Ser. Ila 329 (3) (1999) 189-196.

[37] P. Serrat, W. Ludwig, B. Navarro \& J.-L. Blazi, Variabilité spatio-temporelle des flux de matière en suspension d'un fleuve côtier méditerranéen : la Têt (France), C. R. Acad. Sci. Paris, série lla 333 (2001) 389-397.

[38] F. Vautier, Dynamique géomorphologique et végétalisation des cours d'eau endigués : l'exemple de l'Isère dans le Grésivaudan, PhD thesis, Institut de Géographie Alpine, Grenoble, 2000 (408 p.).

[39] G. Vezzoli, Erosion in the Western Alps (Dora Baltea Basin): 2. Quantifying sediment yield. Sedimentay Geology 171 (2004) 247-259.

[40] H. Vivian, Les crues de l'Isère à Grenoble et l'aménagement actuel des digues. Rev. de Géogr. Alpine, tome LVIII, 1 (1969) 53-84.

[41] H. Vivian, Erosion et transports solides dans le bassin du Drac au Sautet. Doc. du BRGM, séminaire national Propriano (Corse) : la gestion régionale des sédiments (1981) 249-357.

[42] D.E. Walling, P. Kane, Temporal variation of suspended sediment properties, IAHS-AISH / Int. Assoc. Hydrol. Sci. 137 (1982) 409-417.

[43] D.D. Walling, D.W. Webb, J.C. Woodward, Some sampling considerations in the design of effective stategies for monitoring sediment-associated transport. IAHS Public., 210 (1992) 279288.

[44] D.E. Walling, Linking land use, erosion and sediment yields in river basins. Hydrolobiologia 410 (2000) 223-240. 